\title{
KLASIFIKASI KONIDIUM BIOTIS AKIBAT PENYAKIT PADA TANAMAN JAGUNG MENGGUNAKAN JARINGAN SYARAF TIRUAN
}

\author{
Frangky Tupamahu ${ }^{1}$, Salman Suleman ${ }^{2}$ \\ ${ }^{1}$ e-mail: frangkytupamahu@poligon.ac.id, ${ }^{2}$, salmansuleman@poligon.ac.id \\ 1,2 Prodi D3 Teknik Informatika Politeknik Gorontalo
}

\begin{abstract}
In the growth of corn, it is undeniable that in the process of growth, farmers often experience problems that appear to occur due to pest and disease disorders of corn since corn is 2 weeks to 10 weeks which attacks the roots, stems, fruits up to the leaves. As a result of these disturbances, of course, have an impact on fluctuations in the production of corn farmers. Disorders of maize before reaching a severe and widespread category generally show signs of changes occurring in these plants which can visually tell that the corn plants are growing abnormal due to infection. Computing technology now has many benefits for solving various problems related to the computer field only. However, computational benefits have been adopted for use in various fields of science, one of which is in agriculture, namely by applying digital image visualization processing techniques. In this study a classification using artificial intelligence of biotic conidium due to diseases of corn in corn plants with the aim to make it easier to detect the type of conidium in corn leaf plant. The results based on the results of analysis using the Multi layer perceptron (MLP) method performed 5 times obtained the results of the classification accuracy of $73 \%-92 \%$ with an average error rate in 5 trials is 0.18408 with an average time to do iteration to be able do the introduction is 10.2 seconds with an average number of iterations 742 . This shows that MLP has a good performance to do classification using the results of the analysis of disease image features based on the GLCM feature.
\end{abstract}

Intisari - Dalam pertumbuhan jagung, tidak dapat dipungkiri bahwasannya dalam proses pertumbuhannya, para petani sering mengalami gangguan yang nampak terjadi yang diakibatkan adanya gangguan hama dan penyakit pada jagung sejak jagung berumur 2 minggu hingga 10 minggu yang menyerang pada akar, batang, buah hingga sampai pada daunnya. Akibat dari adanya gangguan tersebut, tentunya memberikan dampak fluktasi pada hasil produksi petani jagung.Gangguan penyakit pada tanaman jagung sebelum mencapai kategori parah dan meluas, pada umumnya menunjukan tanda dengan adanya perubahan yang terjadi pada tanaman tersebut yang secara visual dapat diketahui bahwasannya tanaman jagung tersebut pertumbuhannya tidak normal akibat terinfeksi penyakit. Teknologi komputasi saat telah banyak memiliki manfaat untuk menyelesaikan berbagai macam persoalan yang berhubungan dengan bidang komputer saja. Akan tetapi maanfaat komputasi telah di adopsi untuk digunakan pada berbagai bidang ilmu salah satunya bidang pertanian yaitu dengan menerapkan teknik pengolahan visualisasi gambar secara digital Pada penelitian ini dilakukan klasifikasi menggunakan kecerdasan buatan konidium biotis akibat penyakit pada jagung tanaman jagung dengan tujuan untuk mempermudah mendeteksi jenis konidium pada daun tanaman jagung. Adapun hasil yang Berdasarkan hasil analisa menggunakan metode Multi layer perceptron (MLP) yang dilakukan sebanyak 5 kali diperoleh hasil akurasi klasifikasi $73 \%$ - 92\% dengan rata-rata laju eror dalam 5 kali percobaan adalah 0.18408 dengan rata-rata waktu untuk melakukan iterasi agar mampu melakukan pengenalan adalah 10.2 detik dengan jumlah iterasi rata-rata 742. Ini menunjukan bahwa MLP memiliki kinerja yang baik untuk melakukan klasifikasi menggunakan hasil analisis fitur gambar penyakit berdasarkan fitur GLCM.

\section{Kata Kunci- Konidia, Patogen, GLCM, jaringan syaraf tiruan}

\section{PENDAHULUAN}

Sebagai saah satu tanaman biji-bijian paling populer di Indonesia, jagung memiliki banyak manfaat yang banyak digunakan oleh masyarakat indonesia, untuk dijadikan bahan baku pakan ternak juga dibeberapa wilayah di Indonesia, pemanfaatkan jagung juga digunakan oleh pelaku usaha mikro dan makro serta menjadi bahan baku utama pada skala industri baik berskala kecil hingga berskala besar sehinga hal tersebut menumbuhkan minat para petani untuk melakukan penanaman jagung dari skala kecil sampai berskala besar agar dapat memenuhi kebutuhan pengguna. Dalam pertumbuhan jagung, tidak dapat dipungkiri bahwasannya dalam proses pertumbuhannya, para petani sering mengalami gangguan yang nampak terjadi yang diakibatkan adanya gangguan hama dan penyakit pada jagung sejak jagung berumur 2 minggu hingga 10 minggu yang menyerang pada akar, batang, buah hingga sampai pada daunnya. Akibat dari adanya gangguan tersebut, tentunya memberikan dampak fluktasi pada hasil produksi petani jagung. Gangguan penyakit pada tanaman jagung sebelum mencapai kategori parah dan meluas, pada umumnya menunjukan tanda dengan adanya perubahan yang terjadi pada tanaman tersebut yang secara visual dapat diketahui bahwasannya tanaman jagung tersebut pertumbuhannya tidak normal akibat terinfeksi penyakit. Oleh para petani jagung yang 
lahannya banyak ditanami Jagung, kelainan pertumbuhan yang disebabkan adanya gangguan penyakit tersebut dianggap wajar dan tidak memiliki dampak pengaruh negatif yang signifikan pada hasil produksi. Untuk dapat mengetahui secara cepat dan tepat kelainan Tanaman jagung akibat penyakit, para ahli pertanian memiliki peran utama dalam membantu para petani untuk mengidentifikasi sebab dari pada kelainan tersebut dengan melakukan teknik pengumpulan sampel penyakit dan diletakan diwadah untuk di teliti di laboratorium menggunakan alat visual yaitu mikroskop [1], [2],[3][4] sehingga diketahui detail penyakit yang menyerang. Hal tersebut kurang efisien dari aspek waktu dan efektif untuk cepat tanggap mengetahui penyakit yang menginfeksi tanaman jagung. Teknologi komputasi saat telah banyak memiliki manfaat untuk menyelesaikan berbagai macam persoalan yang berhubungan dengan bidang komputer saja[5]. Akan tetapi maanfaat komputasi telah di adopsi untuk digunakan pada berbagai bidang ilmu salah satunya bidang pertanian yaitu dengan menerapkan teknik pengolahan visualisasi gambar secara digital yang dibuktikan dengan adanya penelitian oleh [6] untuk melakukan dekteksi secara otomatis jumlah spora pada tanaman dan [7] dalam penelitiannya melakukan review terkait pemafaatan teknologi pengolaan citra yang diaplikasikan pada pertanian. Adapun Pada penelitian ini dilakukan klasifikasi menggunakan kecerdasan buatan konidium biotis akibat penyakit pada jagung tanaman jagung dengan tujuan untuk mempermudah mendeteksi jenis konidium pada daun tanaman jagung.

\section{METODE PENELITIAN}

Berikut ini adalah langkah-langkah yang dilakukan untuk mengklasifikasi konidium Biotis akibat penyakit pada tanaman jagung menggunakan jaringan syaraf tiruan dan teknik pengolahan citra:

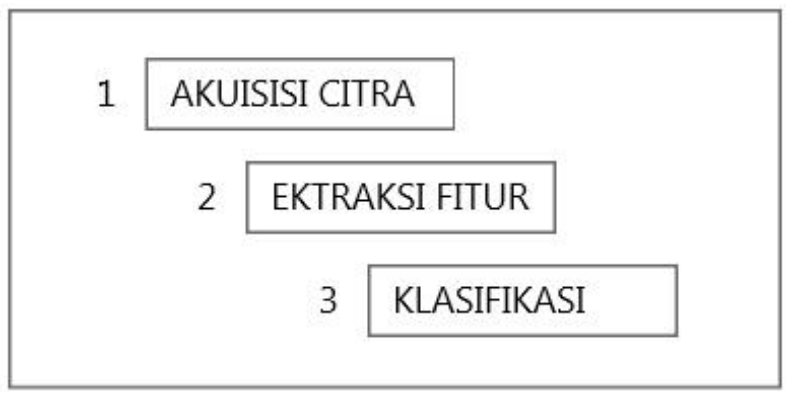

\subsection{Akuisisi Gambar}

Gambar 1. Blok diagram proses Klasifikasi Biotis penyakit tanaman jagung.

Data yang digunakan pada penelitian ini, dalam proses pengambilan datanya menggunakan 2 cara yaitu pertamatama, pengambilan dengan menggunakan sensor CCD kamera Canon 20 Mega Pixels di 4 lokasi yakni : 1). Kabupaten Pohuwato pada tanaman jagung yang berumur 5 - 9 minggu setelah ditanam. 2) Kabupaten Boalemo pada jagung berumur 4-10 Minggu. 3) Kabupaten Gorontalo pada jagung 3 - 10 Minggu. 4) Kabupaten Gorontalo Utara pada jagung yang berumur 5 minggu setelah ditanam. Cara yang kedua, setelah penyakit pada daun diperoleh dengan kamera digital, dilakukan pengguntingan dan pemotongan bagian daun yang terserang penyakit, kemudian dimasukan dalam kantong koleksi dan diberi label dan keterangan sesuai dengan hama dan penyakit penyebab gejala pada tanaman jagung selanjutnya dilakukan pengujian pada laboratorium.
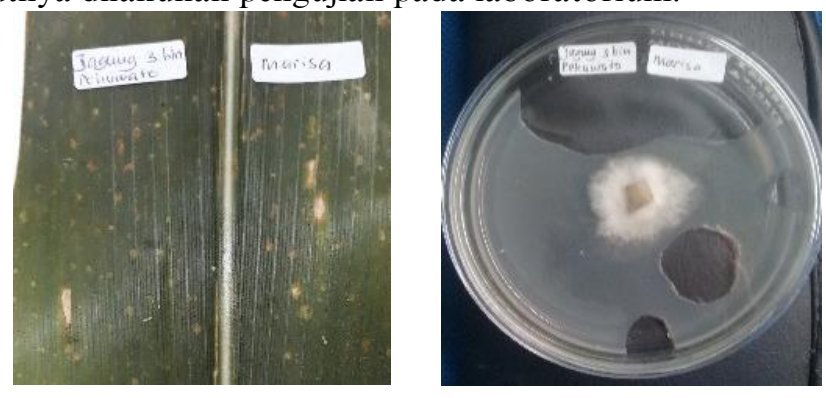

\section{Gambar 2. Hasil Penyakit pada daun dan telah dimasukan pada postulat koch}

Penelitian ini berfokus pada konidium penyakit Hawar, Bercak dan Karat yang menyerang pada daun tanaman jagung dengan jumlah masing-masing penyakit sebanyak 30 gambar dengan kondisi dan sudut pengambilan gambar secara acak yang kemudian keseluruhan gambar tersebut disimpan dalam media digital untuk diolah lebih lanjut menggunakan PYTHON. 


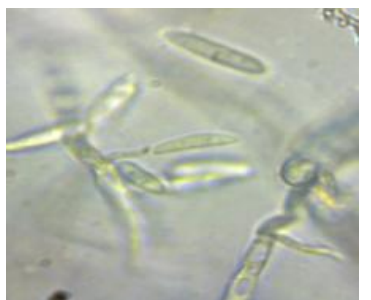

a. Hawar

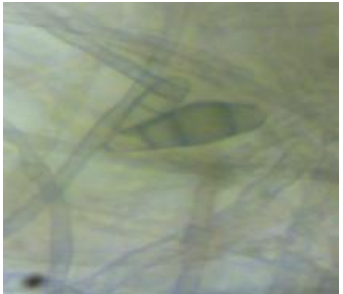

b. Bercak

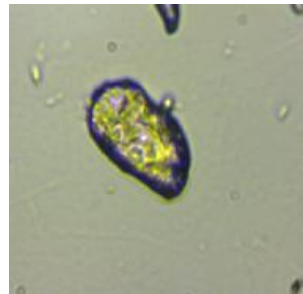

c. Karat

Gambar 2. Konidium Penyakit pada Tanaman Daun Jagung.

\subsection{Ektraksi Ciri Gambar}

Dalam pemrosesan agar mempermudah pengenalan atau pengklasifikasian, telah menjadi syarat utama yang dilakukan yaknik mengekstraksi informasi pada citra digital berdasarkan perubahan morfologi pada penyakit yang pada penelitian ini proses untk mendapatkan informasi dengan cara melakukan ektraksi, yakni berdasarkan tekstur hasil transformasi dari model ruang warna R,G,B ke dalam bentuk Derajat keabuan. Pada penelitian ini digunakan teknik GLCM (Grey Level Co-Occurance Matri) dengan 4 parameter utama yakni dari 9 parameter GLCM yang ada. pertama, menggunakan paramater nilai kontras, kedua paramater entropy, ketiga paramter IDM dan keempat paramater momen angular kedua yang ditiap-tiap parameter tersebut dihitung berdasarkan jarak vektor $(d)=1$ pixel dengan sudut $(\theta)=0,45,90$ dan 135 derajat maka informasi data terkait penyakit telah diketahui dan di simpan dalam basisdata untuk digunakan pada proses klasifikasi.

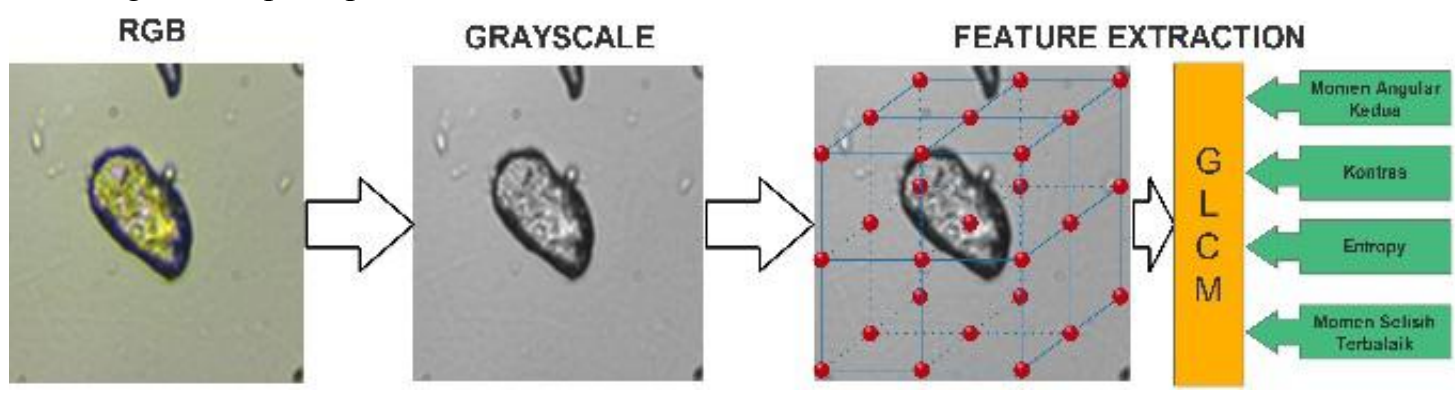

Gambar 3. Proses ektraksi Fitur Menggunakan GLCM

Momen Angular Kedua

$$
f(x, y)=\underset{x}{\gg} \underset{y}{\gg} p 2(x, y)
$$

Kontras

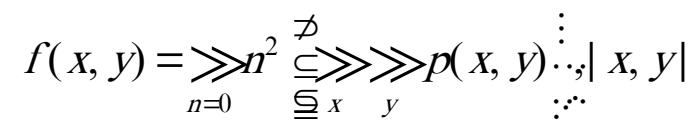

Entropy

$$
f(x, y)=\underset{x}{\gg} \gg_{y} p(x, y) \log (p(x, y))
$$

Momen Selisih Terbalik

$$
f(x, y)=\gg_{x} \gg_{y} \frac{1}{1+\left(x^{-} y\right)^{2}} p(x, y)
$$

\section{HASIL DAN PEMBAHASAN}

Selanjutnya vektor fitur tersebut dianalisa menggunakan Multi layer Perceptron dan diperoleh hasil pengujian sebagai berikut. Pengujian pertama dilakukan menggunakan jumlah data latih sebanyak 81 dan data yang diujikan sebanyak 9 diperoleh hasil secara visual ditunjukan pada gambar 4 - 8 yang menerangkan bahwa untuk mencapai kriteria MSE membutuhkan waktu iterasi yang bervariasi yakni 3, 5, 14 dan 26 detik untuk mencapai target eror 0.001 


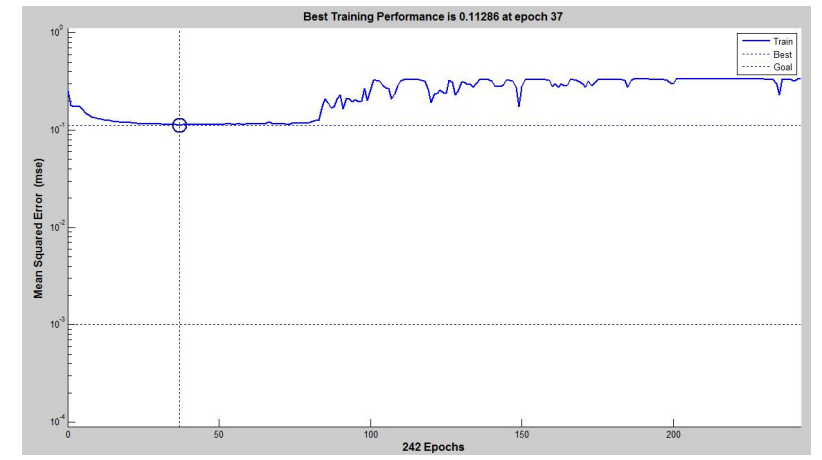

Gambar 4. Grafik Kinerja Percobaan menggunakan 81 data latih dan 9 data Uji

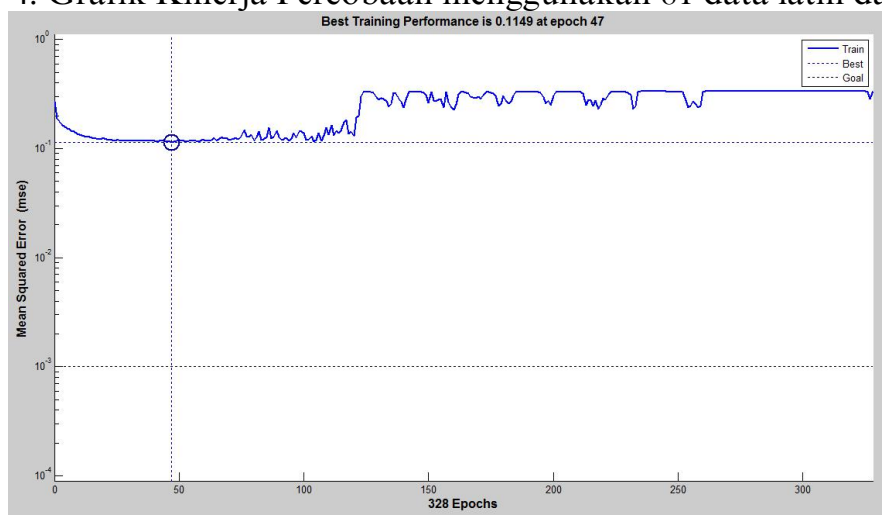

Gambar 5. Grafik Kinerja Percobaan menggunakan 72 data latih dan 18 data Uji.

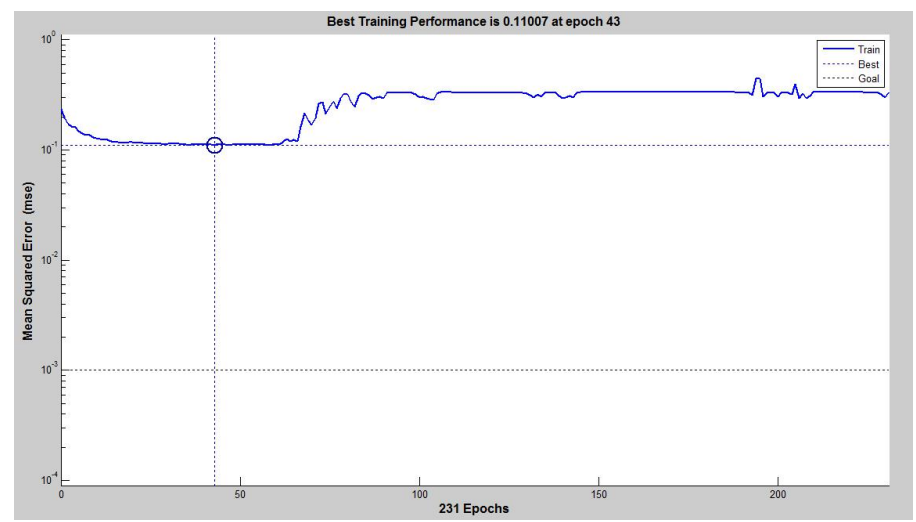

Gambar 6. Grafik Kinerja Percobaan menggunakan 63 data latih dan 27 data Uji

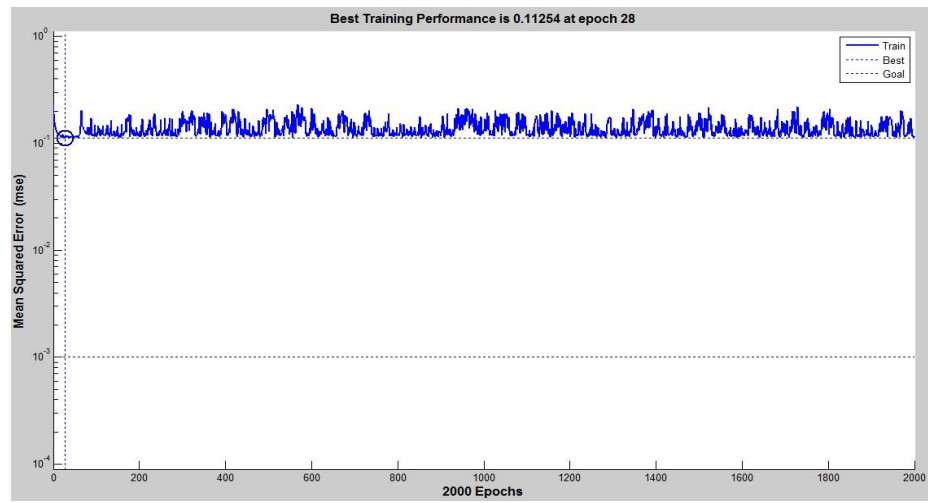

Gambar 7. Grafik Kinerja Percobaan menggunakan 54 data latih dan 36 data Uji. 


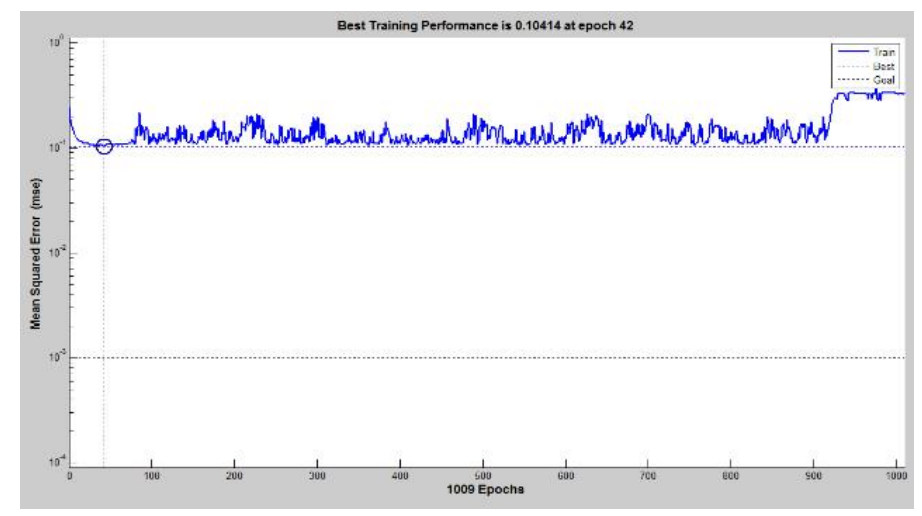

Gambar 8. Grafik Kinerja Percobaan menggunakan 45 data latih dan 45 data Uji.

\section{IV.KESIMPULAN}

Dengan menggunakan 30 data citra penyakit diperoleh hasil bahwa, untuk penyakit bercak memiliki intensitas warna Hue 5 - 12.5, penyakit hawar memiliki intensitas warna $7-18.8$ dan bulai $65-127$. kemudian dilanjutkan pengukuran ciri dengan fitur luminitas $\mathrm{Y}$ diperoleh intensitas untuk penyakit bercak 0.24,hawar 0.32 dan bulai -0.2 0.75. selanjutnya pencirian menggunakan fitur CIE L*a*b diperoleh nilai intensitas dari kecerahan luminitas $L^{*} 5-60$ untuk penyakit bercak dan $18-80$ untuk penyakit hawar serta bulai $100-175$. Ini menunjukan fitur HIS,Lab dan Yuv memiliki kemampuan untuk dijadikan atribut pembeda dari masing-masing citra penyakit.

Berdasarkan hasil analisa menggunakan metode Multi layer perceptron (MLP) yang dilakukan sebanyak 5 kali diperoleh hasil akurasi klasifikasi $74 \%$ - 94\% dengan rata-rata laju eror dalam 5 kali percobaan adalah 0.17408 dengan rata-rata waktu untuk melakukan iterasi agar mampu melakukan pengenalan adalah 11.2 detik dengan jumlah iterasi rata-rata 762. Ini menunjukan bahwa MLP memiliki kinerja yang baik untuk melakukan klasifikasi menggunakan hasil analisis fitur gambar penyakit HIS, $\mathrm{L} a * b *$ dan Yuv.

\section{UCAPAN TERIMA KASIH}

Judul untuk ucapan terima kasih dan referensi tidak diberi nomor. Terima kasih disampaikan kepada Tim JTII yang telah meluangkan waktu untuk membuat template ini.

\section{REFERENSI}

[1] L. Q. Aini, L. Suryani, A. N. Sugiharto, and A. L. Abadi, "Identification of bacterial wilt and leaf blight disease on maize (Zea mays) found in Kediri, Indonesia," Agrivita, vol. 35, no. 1, pp. 1-7, 2013.

[2] W. Shen, Y. Wu, Z. Chen, and H. Wei, "Grading method of leaf spot disease based on image processing," in Proceedings - International Conference on Computer Science and Software Engineering, CSSE 2008, 2008, vol. 6, pp. 491-494.

[3] M. A. N. Patil and M. V. Pawar, "Detection and Classification of Plant Leaf Disease," Iarjset, vol. 4, no. 4, pp. $72-75,2017$.

[4] M. A. Hairuddin, N. Md Tahir, and S. R. S. Baki, "Overview of image processing approach for nutrient deficiencies detection in Elaeis Guineensis," Proc. - 2011 IEEE Int. Conf. Syst. Eng. Technol. ICSET 2011, pp. $116-120,2011$.

[5] I. Ma нn, M. Petrů, I. Ma нn, and M. Petrů, "Trends of Engineering Systems Evolution and Trends of Engineering Systems Evolution and Agricultural Technology Agricultural Technology."

[6] R. Korsnes, K. Westrum, E. Flwistad, and I. Klingen, "Computer-assisted image processing to detect spores from the fungus Pandora neoaphidis," MethodsX, vol. 3, pp. 231-241, 2016.

[7] A. Vibhute and S. K. Bodhe, "Applications of Image Processing in Agriculture: A Survey," Int. J. Comput. Appl., vol. 52, no. 2, pp. 34-40, 2012. 